\title{
Managing Problems and Planning Activities Involving ICT Tools in Teaching ESL Reading and Writing
}

\author{
Melor Md Yunus ${ }^{1}$, Norazah Nordin ${ }^{1}$, Hadi Salehi ${ }^{1,2}$, Mohamed Amin Embi ${ }^{1} \&$ Zamri Mahamod $^{1}$ \\ ${ }^{1}$ Faculty of Education, Universiti Kebangsaan Malaysia (UKM), Bangi, Malaysia \\ ${ }^{2}$ Faculty of Literature and Humanities, Najafabad Branch, Islamic Azad University, Najafabad, Isfahan, Iran \\ Correspondence: Hadi Salehi, Faculty of Literature and Humanities, Najafabad Branch, Islamic Azad University, \\ Najafabad, Isfahan, Iran. Tel: 60-17-653-8260. E-mail: hadisalehi1358@yahoo.com
}

\author{
Received: March 25, 2013 Accepted: May 21, 2013 Online Published: August 1, 2013 \\ doi:10.5539/ass.v9n10p222 URL: http://dx.doi.org/10.5539/ass.v9n10p222
}

\begin{abstract}
The use of Information and Communication Technology (ICT) in English as a Second Language (ESL) teaching and learning has been one of the most widely discussed issues in the field of education. Various activities which involve the use of ICT could be adapted to assist the instruction of reading and writing. However, the teachers need to take note on several matters in managing problems which could arise from the activities planned. The purpose of this study is to identify how the teachers manage problems and plan activities involving ICT tools in teaching ESL reading and writing. To achieve the purpose of the study, a total of 19 secondary school English teachers were interviewed. The teachers were pragmatically and purposively selected from three different areas of Malaysia, 4 teachers from Kuala Lumpur, 7 teachers from Alor Setar and 8 teachers from Tawau, respectively. The findings of the study revealed that the teachers seemed to be weak in managing the problems occurred while using ICT in the teaching of ESL reading and writing. It was also concluded that the teachers' creativity level seemed to be quite low as the activities planned only involve those of lower levels. Moreover, ICT is mostly used to search for reading and writing materials before teaching the new lesson. The findings of the study are hoped to provide the teachers and policymakers with a better and more accurate picture for managing problems and planning activities involving ICT tools in teaching ESL reading and writing.
\end{abstract}

Keywords: information and communication technology (ICT), English as a second language (ESL), reading, writing, teaching, learning

\section{Introduction}

Information and Communication Technology (ICT) has changed the language learning and literacy acquisition environment as well as the dynamics of the language learning settings (Young, 2003). This statement is further supported by Melor Md Yunus (2007) and Salehi \& Salehi (2012) that ICT offers a variety of learning opportunities for students to learn language. Indeed, ICT is capable of improving access to and promote equity in education by providing educational opportunities to a greater number of people of all ages (Yunus \& Salehi, 2012). Besides, as discussed by $\mathrm{Ng}$, Miao \& Lee (2009), ICT can enhance the quality of teaching and learning by providing access to a great variety of educational resources and by enabling participatory pedagogies. ICT can also improve the management of education through more efficient administrative processes, including human resource management, monitoring and evaluation, and resource sharing (Yunus, Salehi \& Chenzi, 2012).

ICT plays a major role in creating a new and improved model of teaching and learning (Kaur, 2008; Salehi \& Salehi, 2011). It seems that English language education nowadays is conceptualized as not only the teaching of language knowledge and skills, but also of language skills for a changing global environment. In fact, Suwannasom (2010) pointed out that since students are living in the world of electronic text where most of the reading and writing is done on electronic screens, teachers need to understand that English as a Foreign Language (EFL) and English as a Second Language (ESL) students cannot afford to practice writing in classrooms if they do not have access to the world of electronic communication. Thus, encouraging the integration of technology in ESL reading and writing instruction is critical for language classrooms and the development of learners' language skills in the Information age. 


\section{Literature Review}

\subsection{The Use of ICT in Education}

Living in this era of modernization, the knowledge age is characterized by challenge and change. The impact of technology takes human beings in competitive arena and necessitates adapting the changes by increasing capacity to know and to do things for catching quality. Technology links people around; the globe is pulled together (Aksal, 2009). Technology has changed the way we communicate, transformed the way we work, and shifted our economy into an information-based, service economy (Sweeny, 2010). There is no doubt that, over the last 15 years, there has been a phenomenal growth in ICT in all aspects of society, and education is not an exception (Unwin, 2007).

The role and function of ICT application in systematic teaching and learning in the classroom is to achieve the objectives of language teaching and learning. Nowadays, schools and institutes provide computers as learning tools for students to gain knowledge and experience. By using computer, the students could easily understand what their teachers or lecturers have taught in the classroom. Internet especially gives more information and students can reach that information faster than usual. It also provides many types of information and at the same time, it could also be a beneficial learning tool in education. Students could gather information from the internet and exchange their views and opinions with other people. This activity is good to be a practice among the students so that the objective of teaching and learning process in the classroom could be achieved. Therefore, ICT can be used as a learning tool in education and a powerful tool in enhancing the teaching and learning process.

\subsection{Managing Problems of Using ICT}

Based on a research conducted by Lawrence, McNeal \& Yildiz (2009), teachers have to take note on several matters in managing problems which could arise from the activities planned. Lattimer (2003) believed that teachers need to organize the curriculum to provide students with opportunities to interact with a wide variety of texts and that students need opportunities to produce their own text. Firstly, teachers need to explain to students how to complete tasks on the computer (e.g., inserting pictures, cutting and pasting pictures into the Word document, changing the size and color of font in their projects). Secondly, when it comes to the brainstorming session, the teacher has to lead the process of brainstorming options for presenting the students' work to the audience based on the type of text the students wanted to share. Thirdly, the teacher cannot take for granted little things which the students might not know. The teacher should make an effort to model certain expected behaviors, for instance, modeling how to write and post an online book review, how to search the Internet for information, and how to save to the Universal Serial Bus (USB) drive. The fourth suggestion is to provide students with suggestions and research strategies to help them progress through the writing process. Lastly, teachers should constantly ask the students questions to ascertain their needs and then guide them through their projects. Proper guidance and scaffolding to guide students along the activities planned using ICT are needed so that all learners are able to follow and benefit from the tasks planned (Lawrence, McNeal \& Yildiz, 2009).

In a different research by Anderson \& Balajthy (2009), although blogs can be a useful tool for the instruction of reading as mentioned above, some researches highlight the drawbacks of using blogs. Two of the drawbacks are that students will not take the work seriously and will not use what they have learned in school in their blog postings. However, as pointed out by West (2008), as educators move from traditional written responses to literature into online forums, they find that students still use the literary discourse from the classroom, along with asserting their own personalities in their posts. This is because students recognize that there is a social context for their work online, they often conform to certain roles or expectations without teacher prompting, because they intend to impress their peers (West, 2008).

This is certainly not the case with all students, so it is important to establish ground rules about your expectations and the type of language that is acceptable in online environments. This is also to avoid the use of harsh or improper language within the online community. Students need to understand that this school-related communication is different from their social conversations with friends outside of school (Lee, 2007). Although technology may initially be a hook for students, careful planning and consideration of the appropriateness of the technology integration will ensure that students remain interested and engaged.

In short, the literature suggests different problem management procedures which depend very much on the problems encountered by the teachers. Some of the problem management skills elaborated above are to organize the curriculum, provide clear explanation to students prior to the tasks given, lead brainstorming sessions, model certain expected behaviors, help students by providing suggestions and research strategies through the writing process, give proper scaffolding along the activities planned and to establish ground rules about teacher expectations and the type of acceptable language in online environments. 


\subsection{Planning Activities Involving ICT in Education}

Various activities which involve the use of ICT could be adapted to assist the instruction of reading and writing. These activities or programmes should not be restricted to in-school activities only. Research has documented that adolescents engage in many literacy practices outside the school (Fisher, 2003 as cited in Lawrence, McNeal \& Yildiz, 2009) because they interact with multiple forms of non-traditional texts and different sources of information, access popular culture and mass media, and communicate with people from diverse backgrounds and perspectives through the use of new technologies.

Collier (2007) reported that students in our 21st-century context increasingly interact with non-traditional texts such as rap lyrics and graphic novels. In this context teachers need to re-examine their classroom practices because of the increasing influence of technology on students' literacy practices. Lawrence, McNeal \& Yildiz (2009) conducted a three-week, campus-based summer literacy program that provided opportunities for adolescents to develop multiple literacy skills and to build upon students' interest in popular culture with traditional academic tasks such as reading, writing, and conducting research to bridge the gap between adolescents' in-school and out-of-school practices. A curriculum was created to build upon the proficiencies the researchers believed the students brought with them to the program (e.g., technology skills and media literacy) to further develop their literacy skills in other areas, namely reading and writing. Some of the lessons included searching for information on the Internet, deconstructing commercials, writing an online book review, and using reading strategies such as making connections and asking questions.

In a different research, Anderson \& Balajthy (2009) discuss the story of an urban school reading project administrator who uses blogs for literature (reading) discussions to help struggling readers achieve long term academic goals. A list with a brief description of each book and a picture of the cover was created and posted on the project website. Students reading the same book were paired up and assigned one of the blog addresses to view and to respond with information about themselves and their book choices. In this project, the teacher identified sources of electronic texts and e-books and determined the reading levels of the students.

In addition, Martinez (2010) examines the different activities which could be planned to incorporate technology into the teaching and learning process. In her article, an example of how schools adapt to the different ways students learn, is that of Eastside High School in Austin, Texas, a traditionally low-performing school, where students are to complete 30 minutes of silent reading twice a week and then $\log$ on to a web site to join a teacher-created group that is essentially a Facebook group for book lovers that includes a discussion board. The teacher posts a discussion topic, and students write about what they have just read. On Fridays, the teacher will lead a face-to-face discussion in class with students who are reading the same book. Facebook, as a social networking tool, has so much to offer in the perspective of education. The use of Facebook in the teaching of reading and writing can be further explored to facilitate the learning process.

In short, various kinds of planning and different types of activities involving ICT in the teaching of reading and writing could be planned. The use of new technologies enables learners to interact with multiple forms of non-traditional texts and different sources of information. Teachers' classroom practices have to be re-examined because of the increasing influence of technology on students' literacy practices. Holiday literacy programmes which cover lessons on reading and writing skills involving the use of ICT could be planned to facilitate students' learning process. Sources of electronic texts and e-books could be identified to help enhance students' reading skills. Teachers can also use the social networking tools such as Facebook and create a group to encourage academic sharing and discussion among the learners.

\section{Methodology}

This study is a qualitative research in nature. The instrument used for this research was a semi-structured interview. A total of 19 secondary school English teachers were interviewed. The teachers were pragmatically and purposively selected from three different areas of Malaysia, 4 teachers from Kuala Lumpur, 7 teachers from Alor Setar and 8 teachers from Tawau, respectively. The questions of the interview were structured to find the answer for the following research questions:

1) How do Malaysian secondary school English teachers manage problems of using ICT in teaching ESL reading and writing?

2) How do Malaysian secondary school English teachers plan activities involving ICT in teaching ESL reading and writing?

The necessary permissions were obtained from both the school principals and the teachers. Moreover, the consent forms were read and signed by all the participants before conducting the interviews. All the interviews 
were conducted in English in September and October 2012. The interviews lasted for about 30 to 45 minutes and they were audio-recorded. After conducting the interviews, the recorded interviews were transcribed verbatim. They were also organized, coded and analyzed. In order to analyze the interview data, several steps have been taken. Right after each interview session, the researcher transcribed the recorded interviews and referred to his notes on what he has jotted down as the interview went along to avoid losing any important data which might become significant to the findings of this research. The researcher then contacted the research interviewees to confirm the accuracy of the transcriptions and notes as interpreted by the researcher. All participants were given a pseudonym for the purpose of anonymity.

\section{Results and Discussion}

\subsection{Participants' Demographic Information}

Table 1 summarizes the details of the interviewed teachers. As it can be seen, 19 secondary school English teachers were selected from three different areas of Malaysia. Fourteen interviewees were female and five interviewees were male. The below table clearly illustrates that only four teachers aged 20 to 30 and the remaining fifteen teachers aged over 30 indicating that the majority of the interviewed English teachers were middle-aged. Most of the teachers had at least 5 years of teaching experience.

Table 1. Basic Information about interviewed teachers

\begin{tabular}{llclc}
\hline Area & Name & Gender & Age & Teaching experience (Year) \\
\hline Alor Setar & Lai & F & 53 & 27 \\
& Norlina & F & 42 & 18 \\
& Fadhil & M & 53 & 30 \\
Siti & F & 42 & 18 \\
& Sarah & F & 37 & 10 \\
Hawau & Hasnah & F & 55 & 34 \\
& Zalilah & F & 45 & 18 \\
& Ida & F & 32 & 9 \\
& Cindy & F & 24 & 1 \\
& Aliff & M & 31 & 7 \\
& Najeeb & M & $40+$ & 22 \\
& Harith & M & 25 & 1 \\
& Hamzah & M & 34 & 11 \\
Kuala Lumpur & Nisa & F & 29 & 4 \\
& Nabihah & F & 28 & 4 \\
& Nora & F & 32 & 9 \\
& Rinie & F & 40 & 15 \\
& Asyikin & F & 46 & 21 \\
& Anne & F & 54 & 30 \\
\hline
\end{tabular}

\subsection{Main Findings of the Interviews}

The main findings of the study are presented based upon the following themes of the research questions:

\subsubsection{Challenges of Using ICT}

Challenges of the use of ICT in teaching reading and writing skills are further explored. The analysis of the interview data indicates that teachers generally felt that the challenge to use ICT in the teaching of reading and writing came from:

1) Lack of computers and maintenance

2) Poor internet access 
3) Lack of technical support

4) Lack of time

1) Lack of Computers and Maintenance

Although the secondary schools should have more advantages and benefits in terms of the funding, facilities and support, it seemed that the interviewed teachers were not satisfied with the facilities of these schools. Nora from a secondary school in Kuala Lumpur explained the problem of the lack of access to modern equipment as follows:

The problem of ICT equipments exist in this school. The computers in the classrooms and computer labs are not maintained. Each classroom has an old computer and a LCD projector. Most of them are not functioning well and are taken out of the classroom.

From the same secondary school in Kuala Lumpur, Rinie shared her frustration dealing with the technical problems of ICT equipments. She explained that:

Most of the time, there is a problem with the LCD to detect the laptop in the computer lab. So when this happens, teachers can get really frustrated and it defeats the purpose of using ICT to aid learning.

Similarly, Lai from a secondary school in Alor Setar seemed frustrated when she described the technical hiccups faced. She also added on the challenge of students talking to one another when there are not enough computers for all the students. She added more points regarding the technical glitches when she said:

Many computers are not functioning well. Those which are functioning well are only a handful. So students have to share the computers and when they sit together and share the computer, they start talking.

Moreover, Hasnah, a very senior teacher in a secondary school in Alor Setar admitted her incompetency in employing ICT-based lessons. She expressed her need for help in utilizing ICT in her teaching. However, she further complained about the lack of technical support in the school when she said:

If I use ICT, I will be having a lot of problems. I am not an IT-savvy person and in this school there is not much of technical support from the technicians. I will have problems connecting the laptop to the $L C D$, the sound system, doing the slideshows and connecting to the internet.

2) Poor Internet Access

The internet has been the main issue which challenged the teachers in their use of ICT. Most of the teachers had unpleasant comments with regards to the internet connection in their schools. For example, Nisa from a secondary school in Tawau got so frustrated about the internet connection and stated that:

It's too slow. Even to load a webpage, it takes years. How are the students going to find a good text and read within the time given? Let's say you have two periods. If you use ICT, you can't finish much. A lot of time will be wasted because of the slow internet connection.

The internet connection also posed a huge problem for Nora who was from a secondary school in Kuala Lumpur. She said,

"We have the YES $4 G$ network but most of the time it's not available. I really don't know how I can depend on the internet here to search for materials." She confirmed the frustration when she said "... the internet is sometimes okay, sometimes down."

3) Lack of Technical Support

Some teachers gave their opinions on the lack of technical support as a challenge for them to use ICT in teaching reading and writing skills. Ida from a secondary school in Tawau illustrated this situation clearly:

We have so many problems with the computers, the LCD, the internet connection and so on but we do not have special technicians who can help us like how the university lecturers have technicians helping them with the technical problems. In schools we don't have such technicians. You have to learn to do everything by yourself. You need to learn to survive in this condition.

Ida's comments above reiterated the challenges on the lack of computers and maintenance as well as the problem of technicalities. Also Zalilah from a secondary school in Alor Setar confirmed this situation by saying:

If I use ICT, I will be having a lot of problems. I am not an IT-savvy person and in this school there is not much of technical support from the technicians. I will have problems connecting the laptop to the $L C D$, the sound system, doing the slideshows and connecting to the internet. 
In his statements above, Zalilah described the problems faced when he integrated ICT in teaching reading and writing skills inside the classroom. Disclosing his incapability in the field of ICT, he pointed out the lack of technical support from the technicians at school.

\section{4) Lack of Time}

The next challenge which prevents teachers to use ICT in education is the lack of time. In a clearer view, the lack of time here refers to the limited amount of time teachers have in their English lessons with the students. Each class has only five periods of English lessons, with 40 minutes allocated for each period. Although 200 minutes per week might seem to be a large amount of time, many teachers are in fact struggling to complete what they have planned for the students. To describe this situation, Rinie from a secondary school in Kuala Lumpur explained that:

A lot of time will be wasted when we use ICT. Like what I've said earlier, when you only have one period of English, you have only 40 minutes. When you use the computer lab, students need some time to get there. If you're lucky, the LCD is alright and it can detect your laptop. If you're not, you'll spend time with the technical problems. Even if you have double periods, you still do not have enough time to finish what you plan to do with the students.

The findings of this section under the challenges of using ICT suggest that the shortage of well-functioning computers, the lack of maintenance on ICT equipments, the slow internet connection in the schools and the lack of time are among the challenges that hinder teachers from utilizing ICT in teaching ESL reading and writing. This reverberates with Melor Md Yunus (2007) findings that teachers can neither teach computer skills nor integrate ICT into the curricula without having at their disposal computers that work.

\subsubsection{Managing Problems Regarding the Use of ICT in ESL Classroom}

Classroom management usually encompasses teachers' actions and aims at managing the ICT facilities in order to engage students in learning process. Specifically, it includes actions such as establishing and maintaining ICT equipment, providing effective instruction, handling of misbehaviors, attending to students' emotional and cognitive needs and managing group processes (Emmer \& Stough, 2001). Therefore, it focuses more on the creation of a positive environment that is conducive to make students involve and they are more satisfied in the learning process. In order to overcome the problems that occur regarding ICT usage in ESL classroom, Hamzah from a secondary school in Tawau stated that:

Teacher could be more creative in thinking and be more active in classroom by giving students lessons which are in agreement with the students' interest or students' level. Therefore, problems regarding the management of students and ICT in ESL classrooms can be overcome easily.

The problem management adapted by the interviewees from the challenges faced was probed. For example, Harith from a secondary school in Tawau stated that "If there are problems, I will change my lessons. I will photocopy exercises from the reference books and teach using those materials". Moreover, Rinie who was a teacher in a secondary school in Kuala Lumpur highlighted the way of assigning take-home tasks to students when there were problems for internet access in school. She added that:

With the problem on slow connection, I will assign students to find reading materials at home and print them out. No matter what, there shouldn't be any spoon feeding. Those materials they find and print out will be useful in their writing process.

Sarah from a cluster school in Alor Setar also had something to say about this matter:

If I really want to use ICT, I will consult the technicians or other teachers who are more expert in ICT to help me. If not, I will just use my own methods of teaching reading and writing without using ICT.

Sarah implied that if there is a will, there is always a way. For her, if she really wanted to use ICT, she would consult the school technicians or her colleagues who were more competent in using ICT. When that did not help, she would just revert to non-ICT teaching methods. As for Asyikin, a teacher in a secondary school in Kuala Lumpur, when she had problems with the ICT tools, she would request for assistance either from the school technicians or the students. She said "I will get the school technicians to help me with the computers. But sometimes they are busy and I will get students to help". The next section presents the findings on how teachers plan activities for teaching ESL reading and writing skills.

\subsubsection{Planning Activities Involving ICT in Teaching Reading and Writing Skills}

Interviewees were also asked to share their plans for reading and writing activities involving the use of ICT in teaching. However, not every interviewee had used ICT in the teaching of reading and writing. Therefore, some ideas were about how they would plan their activities without the use of ICT. 
1) Planning Activities in the Teaching of Reading Skills

For the teaching of reading, Fadhil from a secondary school in Alor Setar reported utilizing the internet to find sample essays for the ESL reading activities. He constructs his own questions with regards to the reading texts to be discussed in class after the reading process. He specifically stated that:

If I have sufficient time, maybe I will find some interesting reading texts from the net. The articles will follow the theme on the students' textbook. I will read through the materials and then send to the school office to make copies for the students. I will form questions to ask my students after reading the tasks.

From a secondary school in Kuala Lumpur, Anne also gave her view on how she usually planned her reading activities. She pointed out that:

As I said earlier, I usually use the textbook for reading comprehension exercises. There are so many reading exercises in the KBSM English textbook. There is one in every chapter in the textbook following the themes set by the CDC (Curriculum Development Division). Students will be exposed to reading skills like skimming and scanning and they will work individually or in groups on the comprehension exercises. And as I said earlier, they will do a lot of silent reading too. Then, we will have a whole-class discussion on the answers for the comprehension exercise.

\section{2) Planning Activities in the Teaching of Writing Skills}

There are so many activities that can be carried out by using ICT in order to teach reading and writing. The programmes and ICT tools to support writing are not like those that are used to support teaching and develop reading activities. In writing activity, using the Word-processors has made a huge difference for many students in learning writing in English language. Students can write pieces of written work for many times over and over again in order to get a neat piece of writing by using ICT tools and present it to the teacher in a neat form of work. To support this idea, Siti from a secondary school in Alor Setar stated that:

Apart from the web-based activities, as a teacher, I use the computers'word processing software for other stages of the class. For example, I use this software during the brainstorming activity. This again is a personal wish to try out teaching a common classroom activity using ICT. I wish to see how the students react to the activity. This again is an attempt to integrate ICT into the class by looking at as many ideas through the web based activities.

Teaching language learners by using ICT has distinct advantages that are related not only to language education but prepares students for today's information society (Nordin, Embi \& Yunus, 2010). Computer technologies and the Internet are powerful tools for assisting language teaching because Web technology is a part of today's social needs, meaning that language learners now can learn through writing e-mail and conducting online research (Wang, 2005; Nordin, et al., 2010). ESL teachers can collect teaching of reading and writing materials by looking at the web based on English language sites. This has been agreed by Norlina who is an English teacher in a secondary school in Alor Setar. She pointed out that:

Teachers can just go to TESL website or any other related web site and just select the suitable materials or activities that can enhance the students' interest in writing. This can be as a reference or just to show evidence for students in gaining more information for future lessons.

Nisa from Tawau referred to her experience regarding the use of ICT in teaching ESL writing. She used ICT in the pre-writing stage and added that:

I use ICT to search for information regarding the topic of writing that I'm going to teach. Let's say I'm about to teach factual writing about pollution. I will search for the information about pollution, the types and details of pollution. Then I print and photocopy the related texts for my students to refer.

Similarly, Rinie from a secondary school in Kuala Lumpur stated that:

My activities will focus more on the pre-writing parts. I will use cartoon strips I get from the net, show the strips to them to attract their attention. Actually, we don't focus much on how to conduct interesting activities for reading and writing activities. We just don't have time for that. We focus more on how to score in the exams. I know having different activities would benefit them but right now, exam is more important. We need to give more drilling practice to them so that they can do well. Here in the cluster school, academic results of the students are just too important for us. We need to maintain a certain grade to make sure the title of 'cluster' will stay.

It should be remembered that teachers must make sure that the websites chosen for learners to browse and search for information are tested to ensure that the language is simple enough for them to understand without having to 
resort to translating the texts word by word. At first, the teachers can introduce the websites which present simple basic information such as meaning or pronunciation of the words that are good for the beginners. However, Hamzah from a secondary school in Tawau believed that the teachers should not be worried about the technology and the way it should be used. He stated that they learn everything because they have been brought up with this technology. He added that:

I do not feel worried about the learners having "techno-fear" since they are young adult learners who have been brought up with IT at home. Therefore, the lesson will be fairly ambitious in allowing learners to freely search on-line. This I hope will lead to greater learner autonomy, as they will be deciding in groups what to look for and to what depth. After the class, I hope to be able to reflect and see how successful I was in caring out the activity by using ICT in my ESL classroom, and what I need to do is to reflect and think a way to improve the integration of ICT into my next classes.

\section{Conclusion}

To manage problems which occurred, teachers reported using the following means. First, modifying lessons and making copies of exercises from the reference books to be distributed as handouts when technical problems occurred. Besides, if they had problems with the ICT equipments, they would revert to consulting the school technicians or other colleagues who are more competent in using ICT. Assistance either from the students was also one of the options used.

Teachers reported utilizing the internet to find sample essays for the ESL reading activities. Questions with regards to the reading texts will be constructed by the teacher to be discussed in class after the reading process. Teachers also reported making use of the reading exercises available in the KBSM English textbook together with discussions with the students in relation to the reading exercise in class. As for writing, an example is to find cartoon strips online to attract students' attention, and to use the internet to look for information (such as facts) to help students in their writing process.

Teachers seemed to be weak in managing the problems occurred while they were using ICT in teaching of reading and writing skills. Feedback given was that if they had problems with the ICT equipments, they would revert to consulting the school technicians or other colleagues who are more competent in using ICT. Assistance either from the students was also one of the options used. Teachers' creativity level seemed to be quite low as the activities planned only involve those of lower levels like using the exercises from the KBSM English textbook. ICT is mostly used to search for reading and writing materials before the lesson.

\section{References}

Aksal, F. A. (2009). Action plan on communication practices: Roles of tutors at EMU Distance Education Institute to overcome social barriers in constructing knowledge. The Turkish Online Journal of Educational Technology, 8(2), 33-47.

Anderson, R., \& Balajthy, E. (2009). Stories about struggling readers and technology. The Reading Teacher, 62(6), 540-542. http://dx.doi.org/10.1598/RT.62.6.9

Collier, L. (2007). The shift to 21-century literacies. The Council Chronicle, 17(2), 4-8.

Emmer, E. T., \& Stough, L. M. (2001). Classroom management: A critical Part of educational psychology with implications for teacher education. Educational Psychologist, 36(2), $103-112$. http://dx.doi.org/10.1207/S15326985EP3602_5

Fisher, M. T. (2003). Open mics and open minds: Spoken word poetry in African diaspora participatory literacy communities. Harvard Educational Review, 73(3), 362-389.

Kaur, S. (2008, March, 23). Making ICT work. The Star Online. Retrieved September 19, 2012, from http://thestar.com.my/education/story.asp?file=/2008/3/23/education/20625954

Lattimer, H. (2003). Thinking through genre: Units of study in reading and writing workshops 4-12. Portland, $\mathrm{ME}$ : Stenhouse.

Lawrence, S. A., McNeal, K., \& Yildiz, M. N. (2009). Summer program helps adolescents merge technology, popular culture, reading, and writing for academic purposes. Journal of Adolescent and Adult Literacy, 52(6), 483-494. http://dx.doi.org/10.1598/JAAL.52.6.3

Lee, C. K. (2007). Affordances and text-making practices in online instant messaging. Written Communication, 24(3), 223-249. http://dx.doi.org/10.1177/0741088307303215

Martinez, M. (2010, October). Teacher education can’t ignore technology. Kappan Magazine, 74-75. 
Ng, W. K., Miao, F., \& Lee, M. (2009). Capacity-building for ICT integration in education. Digital Review of Asia Pacific 2009-2010, 67-76

Nordin, N., Embi, M. A., \& Yunus, M. M. (2010). Mobile learning framework for lifelong learning. ProcediaSocial and Behavioral Sciences, 7, 130-138. http://dx.doi.org/10.1016/j.sbspro.2010.10.019

Nordin, N., Hamzah, M. I., Yunus, M. M., \& Embi, M. A. (2010). The mobile learning environment for the in-service school administrators. Procedia - Social and Behavioral Sciences, 7, 671-679. http://dx.doi.org/10.1016/j.sbspro.2010.10.091

Salehi, H., \& Salehi, Z. (2011). Washback effect of high-stakes tests on ICT usage: Teachers' perceptions. Australian Journal of Basic and Applied Sciences, 5(12), 1976-1984.

Salehi, H., \& Salehi, Z. (2012). Integration of ICT in language teaching: Challenges and barriers. Proceedings of the 3rd International Conference on e-Education, e-Business, e-Management and e-Learning (IC4E, 2012), IPEDR vol. 27: 215-219.

Suwannasom, T. (2010). Teacher cognition about technology-mediated EFL instruction in the Thai tertiary context. PhD Dissertation, College of Education, Massey University, New Zealand.

Sweeny, S. M. (2010). Writing for the instant messaging and text messaging generation: Using new literacies to support writing instruction. Journal of Adolescent and Adult Literacy, 54(2), 121-130. http://dx.doi.org/10.1598/JAAL.54.2.4

Unwin, A. (2007). The professionalism of the higher education teacher: What's ICT got to do with it? Teaching in Higher Education, 12(3), 295-308. http://dx.doi.org/10.1080/13562510701278641

Wang, L. (2005). The advantages of using technology in second language education. Technology Horizons in Education Journal, 38-41.

West, K. (2008). Weblogs and literary response: Socially situated identities and hybrid social language in English class blogs. Journal of Adolescent \& Adult Literacy, 51(7), 588-598. http://dx.doi.org/10.1598/JAAL.51.7.6

Young, S. S. C. (2003). Integrating ICT into second language education in a vocational high school. Journal of Computers Assisted Learning, 19, 447-461. http://dx.doi.org/10.1046/j.0266-4909.2003.00049.x

Yunus, M. M. (2007). Malaysian ESL teachers' use of ICT in their classrooms: Expectations and realities. European Association for Computer Assisted Language Learning. ReCALL, 19(1), 79-95. http://dx.doi.org/10.1017/S0958344007000614

Yunus, M. M., \& Salehi, H. (2012). The effectiveness of Facebook groups on Teaching and Improving Writing: Students' perceptions. Journal of Education and Information Technologies, 1(6), 87-96.

Yunus, M. M., Salehi, H., \& Chenzi, C. (2012). Integrating social networking tools into ESL writing classroom: Strengths and weaknesses. English Language Teaching, 5(8), 42-48. http://dx.doi.org/10.5539/elt.v5n8p42

\section{Copyrights}

Copyright for this article is retained by the author(s), with first publication rights granted to the journal.

This is an open-access article distributed under the terms and conditions of the Creative Commons Attribution license (http://creativecommons.org/licenses/by/3.0/). 